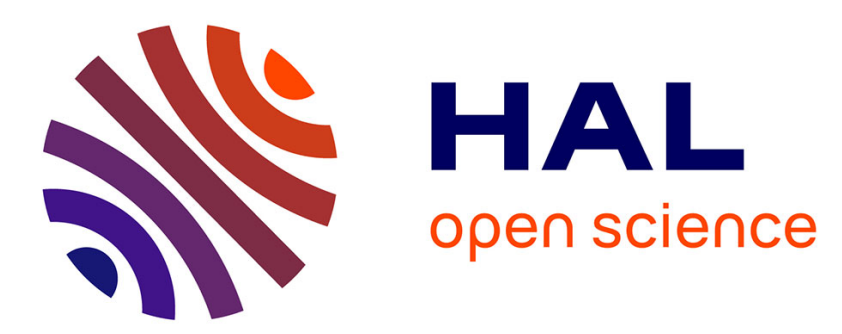

\title{
Investigating the role of pectin in carrot cell wall changes during thermal processing: A microscopic approach
}

\author{
Albert Ribas, Sandy van Buggenhout, Paola Palmero, Marc Hendrickx, Ann \\ van Loey
}

\section{- To cite this version:}

Albert Ribas, Sandy van Buggenhout, Paola Palmero, Marc Hendrickx, Ann van Loey. Investigating the role of pectin in carrot cell wall changes during thermal processing: A microscopic approach. Innovative Food Science \& Emerging Technologies / Innovative Food Science and Emerging Technologies , 2014, 24, pp.113-120. 10.1016/j.ifset.2013.09.005 . hal-01292872

\section{HAL Id: hal-01292872 \\ https://hal.science/hal-01292872}

Submitted on 23 Mar 2016

HAL is a multi-disciplinary open access archive for the deposit and dissemination of scientific research documents, whether they are published or not. The documents may come from teaching and research institutions in France or abroad, or from public or private research centers.
L'archive ouverte pluridisciplinaire HAL, est destinée au dépôt et à la diffusion de documents scientifiques de niveau recherche, publiés ou non, émanant des établissements d'enseignement et de recherche français ou étrangers, des laboratoires publics ou privés. 
Version définitive du manuscrit publiée dans / Final version of the manuscript published in : Innovative Food Science and Emerging Technologies (2014), Vol. 24, p. 113-120, DOI: 10.1016/j.ifset.2013.09.005 - Journal homepage : www.elsevier.com/locate/ifset

\title{
Investigating the role of pectin in carrot cell wall changes during thermal processing: A microscopic approach
}

\author{
Albert Ribas-Agustí, Sandy Van Buggenhout, Paola Palmero, Marc Hendrickx, Ann Van Loey * \\ Laboratory of Food Technology, Leuven Food Science and Nutrition Research Centre (LFoRCe), Department of Microbial and Molecular Systems (M²S), KU Leuven, \\ Kasteelpark Arenberg 22 Box 2457, 3001 Heverlee, Belgium
}

\begin{abstract}
A B S T R A C T
Changes in cell wall integrity upon thermal treatment were assessed in carrot cells using novel microscopic approaches using Congo red and different cell wall polysaccharide specific probes (JIM7, LM10, LM11, LM15, LM21, LM22 and CBM3a). Strong thermal processing induced an increased accessibility of cellulose and hemicelluloses by Congo red and the specific probes, except galactomannan, which detection was not affected by the thermal processing. Detection of pectin by JIM7 disappeared upon thermal processing, pointing at the leaching out effect of pectin from cell wall due to $\beta$-elimination. Changes observed after thermal processing were moreover similar to changes observed after enzymatic degradation of pectin, and a combination of thermal and pectinases treatments did not cause additional effects. These observations indicated that the presence of native pectin is the main factor governing cell wall polysaccharides accessibility and overall cell wall integrity in carrot, which can be modulated through thermal processing.

Industrial relevance: This work provides new evidences on the specific role of pectin in carrot cell wall integrity, more specifically on how it can be modulated by thermal processing. New light microscopy approaches to assess changes in cell wall integrity are presented. This information is important for food industry since plant cell wall acts as a structural barrier for the release of carotenoids and other micronutrients in plant-based food products.
\end{abstract}

\section{Introduction}

Plant cells are surrounded by a cell wall, a structure which confers mechanical protection and structural support to cells and at the same time enables the interaction between neighbouring cells and with the surrounding medium. The primary cell wall and the middle lamella are basically composed of polysaccharides, but also contain minor amounts of glycoproteins and phenolic compounds (Sandhu, Randhawa, \& Dhugga, 2009). Cellulose is a polysaccharide composed of $\beta(1 \rightarrow 4)$ linked D-glucoses and is assembled into long microfibrils (Thomas et al., 2013). Other glucosyl polysaccharides, known as hemicelluloses, are characterised by the fact that they are soluble in alkali but cannot be solubilised using chelating agents. The hemicellulose group includes xyloglucan, xylans (arabinoxylan, glucuronoxylan and glucuronoarabinoxylan), mannans (glucomannan, galactomannan and galactoglucomannan) and arabinogalactan (O'Neill \& York, 2003). A third group of cell wall polysaccharides are known as pectic

Abbreviations: CBM, carbohydrate-binding module; CR, Congo red; FITC, fluorescein isothiocyanate; HSI, hue, saturation and intensity; MPBS, milk-phosphate buffered saline; NA, numerical aperture; PBS, phosphate buffered saline; PG, polygalacturonanase; PME, pectinmethylesterase.

* Corresponding author. Tel.: +32163215 67; fax: + 3216321960

E-mail address: ann.vanloey@biw.kuleuven.be (A. Van Loey)

URL: https://www.biw.kuleuven.be/m2s/clmt/lmt/ (A. Van Loey). polysaccharides or pectin. It is a heterogeneous group of polysaccharides that have $\alpha(1 \rightarrow 4)$ linked D-galacturonic acid unities in the structure. Homogalacturonan is the major pectic polysaccharide, consisting of linear polymers of galacturonic acid with varying pattern and degree of methyl esterification. Rhamnogalacturonan I is another pectic polysaccharide with a backbone composed of galacturonic acid and rhamnose with linear and branched side chains of galactose and arabinose residues. Other pectic polysaccharides have a backbone of galacturonic acid with side chains containing rhamnose and different other neutral sugars (rhamnogalacturonan II and other substituted galacturonans) (Willats, McCartney, Mackie, \& Knox, 2001).

The cell wall has been described as a system of two independent but interacting networks, one formed of cellulose cross-linked with hemicelluloses and another composed of pectin (O'Neill \& York, 2003). However, other studies have found evidence of strong interactions between pectin and the other cell wall compounds (Thompson \& Fry, 2000; Wang, Zabotina, \& Hong, 2012), and propose a new paradigm for the cell wall structure, with a single network of pectin, cellulose and hemicellulose. Anyhow, it is well known that pectic polysaccharides create an intricate structure reinforced with pectin-pectin and ionic interactions (Morris, Ring, MacDougall, \& Wilson, 2003). It is believed that cellulose and hemicelluloses, within the cell wall, function as a load-bearing structure, while pectin controls the porosity of the cell wall, preventing the free diffusion of macromolecules such as enzymes. The exact polymer interactions within this network however still 
remain unclear (Agoda-Tandjawa, Durand, Gaillard, Garnier, \& Doublier, 2012).

The chemical fine-structure of the cell wall and the interactions within the polysaccharide network considerably affect the functional properties of vegetable-based food products, such as texture and rheology (De Roeck, Sila, Duvetter, Van Loey, \& Hendrickx, 2008), as well as may determine to what extent it acts as a barrier to the release of lipophilic micronutrients from inside cells, such as carotenoids (Morris et al., 2003). Carrot cells contain $\beta$-carotene, which has interesting health-promoting properties due to their antioxidant and provitamin A activity (Nishino, Murakoshi, Tokuda, \& Satomi, 2009; Rao \& Rao, 2007). The barrier properties of the carrot cell wall are therefore an important issue from the nutritional point of view, since carotenoids need to be bioaccessible (i.e., they must be released from the food matrix and incorporated into micelles during digestion before being absorbed) prior to exhibit their benefits for health. The importance of cell walls for the bioaccessibility of carrot carotenoids has been shown in this context (Lemmens, Van Buggenhout, Van Loey, \& Hendrickx, 2010; Moelants, Lemmens, Vandebroeck, Van Buggenhout, Van Loeyet al. 2012; Palmero et al., 2013); however, insight into the role of each type of polysaccharide in the structure, integrity and consequently, in its barrier properties and permeability of the cell wall is currently lacking.

By food processing, it is possible to change the microstructure of the cell wall, and food processes may be designed to improve the rheological or nutritional properties of food products (Jolie et al., 2012; Van Buggenhout et al., 2012). Thermal treatment, for instance, is known to affect cell wall integrity and carotenoid bioaccessibility in carrots (Knockaert, Lemmens, Van Buggenhout, Hendrickx, \& Van Loey, 2012; Lemmens, Colle, Van Buggenhout, Van Loey, \& Hendrickx, 2011). The relation between thermal treatment conditions, cell wall microstructural changes and how these changes are related to changes in the cell wall barrier properties is however still not well understood (Van Buggenhout et al., 2010). Several recently-developed molecular probes that allow specific localization and visualization of certain cell wall polysaccharides (Wallace \& Anderson, 2012) could help us to understand these changes. The use of antibodies in combination with fluorescence light microscopy, which is known as immunofluorescence, has been successfully employed to recognise polysaccharides and their exact localization in plant tissue-based preparations (Christiaens et al., 2011; Knox, 1997; Willats et al., 2000). The objective of the present work was to use these probes to investigate the specific role of pectin in the cell wall of carrot tissue, in the context of thermally-induced changes of cell wall integrity. In addition, it was evaluated whether Congo red (CR), a dye traditionally used for cell wall staining (Wood, Fulcher, \& Stone, 1983), could provide an alternative for this immunofluorescence approach. Next to thermal treatments, enzyme (pectin methylesterase, PME, and polygalacturonanase, PG) treatments were applied in order to check whether thermally-induced cell wall changes were indeed related to changes in the pectic polymers.

\section{Materials and methods}

\subsection{Sample preparation and thermal treatment}

Fresh carrots (Daucus carota L. cv. Nerac), purchased in a local retailer, were peeled, cut into pieces and blended in a kitchen blender for 1 min with 1 volume of deionised water. Small cell cluster fractions were isolated from the puree by wet sieving, using a sieve shaker (Retsch, Aartselaar, Belgium) equipped with 40 and $250 \mu \mathrm{m}$ pore size sieves. Since microscope observations showed that the average carrot cell size is $61.4( \pm 15.2) \mu \mathrm{m}$, the samples prepared for this study contained particles with a limited number of cells (estimated between 1 and 100 cells). A single batch of homogeneous puree obtained from $2 \mathrm{~kg}$ of raw carrot was used for the thermal and enzyme treatment, which was performed once.
Carrot samples, consisting of carrot small cell clusters immersed in deionised water as a heating medium, were inserted into stainless steel tubes ( $3 \mathrm{~mm}$ inner diameter) and plunged for $25 \mathrm{~min}$ in an oil bath preheated at $95,105,115$ and $125^{\circ} \mathrm{C}$.

\subsection{Enzyme treatment}

The applied enzyme treatment consisted of a two-step treatment with two purified pectinases: a first incubation step with pectinmethylesterase (PME, EC 3.1.1.11) from Aspergillus aculeatus (Novozymes, Bagsværd, Denmark), and a second incubation with polygalacturonase M2 (PG, EC 3.2.1.15) from A. aculeatus (Megazyme, Bray, Ireland). PME catalyses the de-esterification of methylated homogalacturonan, which once de-esterified, is further depolymerised by PG. Carrot samples were incubated in centrifuge tubes containing pH $4.5100 \mathrm{mM}$ sodium phosphate buffer medium and 7 U PME per $\mathrm{g}$ of carrot puree. After $2 \mathrm{~h}$ of incubation, the tubes were centrifuged $(22,100 \times \mathrm{g}, 10 \mathrm{~min})$, the supernatant removed and the carrot cell clusters were resuspended in pH $5.5100 \mathrm{mM}$ sodium phosphate buffer and centrifuged $(22,100 \times \mathrm{g}, 10 \mathrm{~min})$. Samples were further washed in phosphate buffer until pH 5.5 was reached. Samples were thereafter added with 50 U PG per $g$ of carrot puree and incubated overnight. All reactions were performed at room temperature while end-over-end rotated. Non enzyme-treated samples also were incubated under these conditions, but without adding the enzymes. Samples were stored in $70 \%(\mathrm{v} / \mathrm{v})$ ethanol at $4{ }^{\circ} \mathrm{C}$ until microscope analysis, which was within a month.

\subsection{Congo red cell wall staining}

Samples were incubated for $2 \mathrm{~h}$ in $100 \mathrm{mg} \cdot \mathrm{l}^{-1} \mathrm{CR}$ (Sigma-Aldrich, Diegem, Belgium) at room temperature, were washed three times with deionised water and placed on a slide for light microscopic observation in bright field and fluorescence modes. Samples were examined using an Olympus BX-41 light microscope (Olympus, Tokyo, Japan) equipped with epifluorescence illumination (EXFO, Hants, UK) and an Olympus XC50 CCD camera (Olympus, Tokyo, Japan). Micrographs of parenchyma cell clusters were taken at $40 \times($ NA 0.75). A 530-550 nm band-pass exciter filter, a $575 \mathrm{~nm}$ barrier filter and a $570 \mathrm{~nm}$ dichroic mirror (Olympus, Tokyo Japan) were used for imaging in fluorescence mode. The microscope and camera settings were kept constant upon comparing different samples. Eight pictures were taken per sample, from which the most representative was selected as image to display.

According to Castleman (1998), 'hue' and 'saturation' are two parameters extracted from the hue, saturation and intensity (HSI) colour space which are normally depending on the light-reactive properties of the dye, while 'intensity' is a third HSI parameter seriously affected by the illumination settings. According to this, the 'sum saturation' value was used to estimate the intensity of the staining in CR experiments using bright field illumination. The measurement was performed in $200 \mu \mathrm{m}^{2}$ squares of ten random cells, clearly not overlaid by other cells. The measurements were done using Cell* v. 2.4 software (Olympus, Tokyo, Japan).

\subsection{Cell wall polysaccharide immunolabelling}

Samples were washed in 70\% ethanol in order to remove carotenoids and minimise autofluorescence prior the immunolabelling. The antihomogalacturonan antibody JIM7 (Plant Probes, Leeds, UK) was used to label pectin. For hemicellulose immunolabelling, five antibodies kindly donated by Prof. Paul Knox from University of Leeds were employed: LM10 (xylan), LM11 (xylan, arabinoxylan), LM15 (xyloglucan), LM21 (mannan, glucomannan and galactomannan) and LM22 (mannan and glucomannan). Hybridoma supernatants were diluted 1:5 in milk-phosphate-buffered saline (MPBS, $140 \mathrm{mM}$ $\mathrm{NaCl}-2.7 \mathrm{mM} \mathrm{KCl}-8.0 \mathrm{mM} \mathrm{Na} \mathrm{HPO}_{4}, \mathrm{pH} 7.4$, containing 3\% milk 
Version définitive du manuscrit publiée dans / Final version of the manuscript published in :

Innovative Food Science and Emerging Technologies (2014), Vol. 24, p. 113-120,

DOI: 10.1016/j.ifset.2013.09.005 - Journal homepage : www.elsevier.com/locate/ifset

powder) and added to the carrot cell clusters. Samples were incubated for $1.5 \mathrm{~h}$ at room temperature. Next, samples were washed in phosphate-buffered saline (PBS) and further incubated with a secondary antibody, an anti-rat Ig-FITC (Nordic Immunology, Tilburg, The Netherlands), which was diluted 1:20 in MPBS. Incubation with the secondary antibody was carried out at room temperature for $1 \mathrm{~h}$ in darkness. Samples were washed with PBS and placed on a slide with antifade agent (Citifluor, Leicester, UK) for microscopic observation.

An anti-crystalline cellulose CBM3a probe (Plant Probes, Leeds, UK) was employed for the detection of cell wall cellulose. CBM3a hybridoma supernatant was diluted 1:100 in MPBS, added to the carrot cell clusters and incubated for $1.5 \mathrm{~h}$ at room temperature. Samples were washed in PBS and further incubated with a secondary antibody, an anti-histidine Ig (Sigma-Aldrich, Diegem, Belgium) 1:1000 in MPBS for $1 \mathrm{~h}$ at room temperature. After washing in PBS, samples were incubated with antimouse Ig-FITC (Nordic Immunology, Tilburg, The Netherlands) 1:50 in MPBS for $1 \mathrm{~h}$. After incubation, samples were washed with PBS, placed on a slide and mounted with anti-fade agent (Citifluor, Leicester, UK) for microscopic observation.

The same microscope and image acquisition settings were kept between pictures in order to compare the fluorescence intensity. Thermally ( $125^{\circ} \mathrm{C}$ for $25 \mathrm{~min}$ ), not thermally and enzymatically or not enzymatically- treated samples were examined using an Olympus BX-41 light microscope (Olympus, Tokyo, Japan) equipped with epifluorescence illumination (EXFO, Hants, UK) and an Olympus XC50 CCD camera (Olympus, Tokyo, Japan). Fluorescence images of parenchyma cell clusters were taken using the $40 \times$ objective (NA 0.75), a 460-495 $\mathrm{nm}$ band-pass exciter filter, a $510 \mathrm{~nm}$ barrier filter and a $505 \mathrm{~nm}$ dichroic mirror (Olympus, Tokyo Japan). Eight pictures were taken per sample, from which the most representative was selected as image to display.

\subsection{Data analysis}

CR saturation values were analysed using SPSS Statistics v.19 (IBM, Armonk, NY, USA). Mean values were analysed with a one-way
ANOVA, and differences between means were assessed by the Tukey test with a level of significance $\alpha=0.05$.

\section{Results and discussion}

\subsection{Effect of thermal processing and enzyme treatment on pectin immunolabelling}

JIM7 has been recommended as a general probe to specifically detect pectin in plant tissue-based samples because this monoclonal antibody recognises homogalacturonans with a very wide range of methylesterification (Christiaens et al., 2011). Fluorescence emitted from carrot cell clusters labelled with JIM7 showed a decreasing trend when increasing the temperature of the treatment (Fig. 1A, B). High temperature is known to cause $\beta$-elimination of pectin, which changes the solubility characteristics of pectin. As a consequence, some of pectic polymers are released into the aqueous medium in which they are thermally treated. Knockaert et al. (2011) found a high concentration of pectin in the serum phase of carrot samples after thermal treatment, and Moelants, Jolie, Palmers, Cardinaels, Christiaens et al. (2012) reported the depolymerisation and solubilisation of pectin in carrot sera due to intense heating. Therefore, we assume that the loss of JIM7 detection in thermally treated cell clusters is a consequence of changes in the pectin structure as well as of the possible loss of pectin from the cell wall.

The efficiency of the enzymatic treatment, aimed to depolymerise the cell wall pectin through the action of PME and PG, was confirmed by JIM7 immunolabelling (Fig. 1C). The samples treated with enzymes only showed very faint fluorescence. In line with these observations, no differences in fluorescence emission were observed between the enzymatically treated samples and samples that underwent the thermal and the enzymatic treatment as well (Fig. 1D). The comparison of the JIM7 labelling of the thermally treated and enzymatically treated samples clearly indicates that cell wall changes induced by thermal processing correspond to changes in the pectic polymers. This observation confirms the fact that pectic polymers are susceptible to changes due to temperature (Sila, Smout, Elliot, Van Loey, \& Hendrickx, 2006).
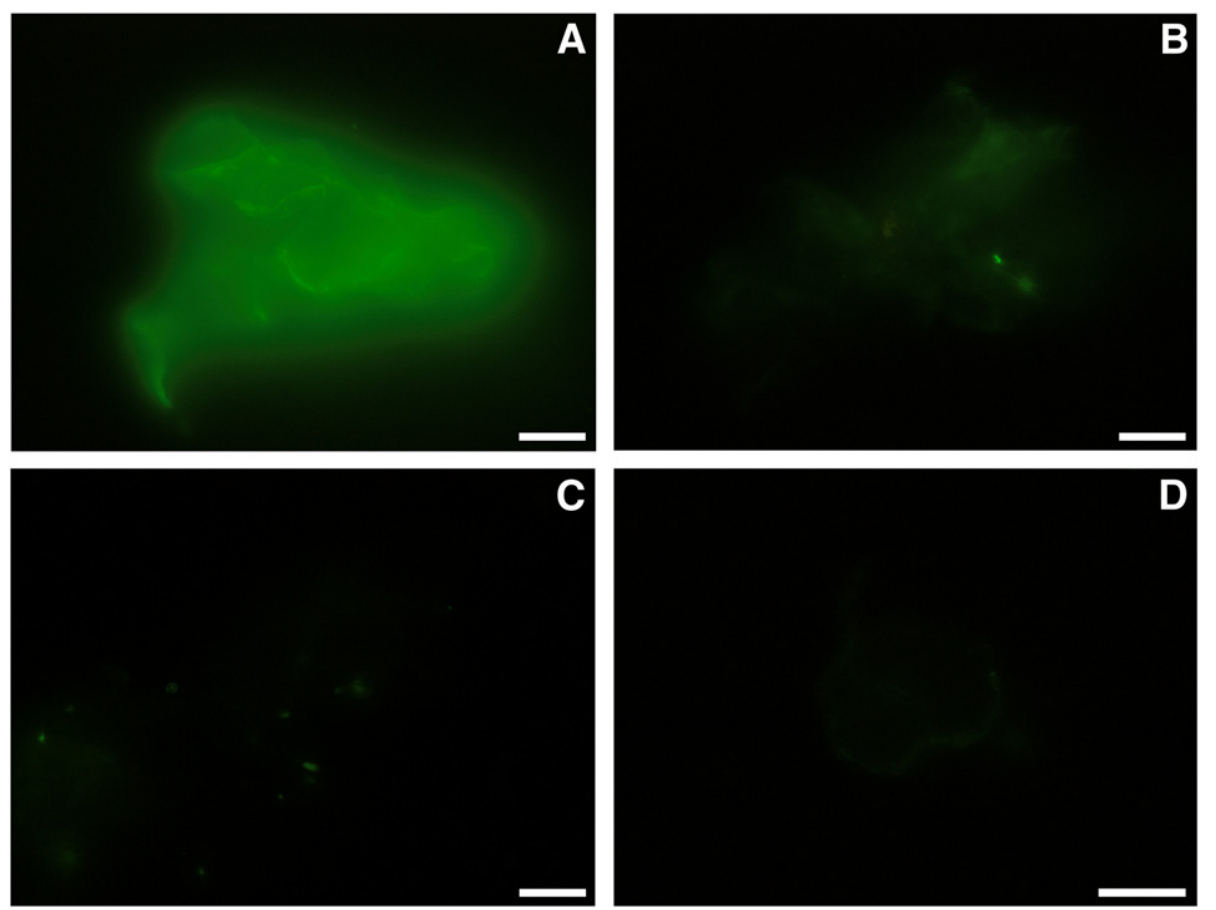

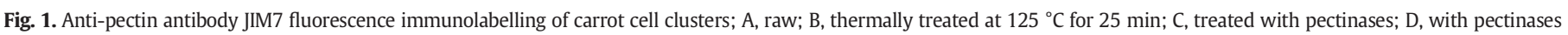
treatment following thermal treatment. Scale bars $=50 \mu \mathrm{m}$. 
Version définitive du manuscrit publiée dans / Final version of the manuscript published in :

Innovative Food Science and Emerging Technologies (2014), Vol. 24, p. 113-120,

DOI: 10.1016/j.ifset.2013.09.005 - Journal homepage : www.elsevier.com/locate/ifset

3.2. Effect of thermal processing and enzyme treatment on Congo red cell wall staining

CR is a dye that exhibits strong interaction with cellulose (Mazeau \& Wyszomirski, 2012; Woodcock, Henrissat, \& Sugiyama, 1995), although interactions with other $(1 \rightarrow 4)-\beta$-D-glucopyranosyl polysaccharides such as xyloglucan have been also described (Wood, 1980). It is widely used for analytical purposes in the field of cell wall polysaccharides (Bhattacharya, Ghosh, Sahoo, Dey, \& Pal, 2010; Lopez-Sanchez et al., 2011; Verbelen \& Kerstens, 2000).

The specificity of CR to the cell walls was made evident by fluorescence imaging, which showed the carrot cells with higher staining intensity at their peripheral areas (Fig. 2). In addition, microscopic observations revealed a more intense staining with CR in carrot cells treated at high temperature (Fig. 2A-E). The sum saturation values acquired from cell walls on micrographs reflected the higher recognition of cellulose and other $(1 \rightarrow 4)$ - $\beta$-D-glucopyranosyl polysaccharides by $\mathrm{CR}$ at higher temperatures; their values are shown in Fig. 3A. Mean saturation values showed an increasing trend above $95{ }^{\circ} \mathrm{C}$ and reached a significant difference at $125^{\circ} \mathrm{C}$.

Enzymatic degradation of pectin also resulted in an increase in the intensity of CR staining (Fig. 2F-J). Combination of thermal and enzymatic treatment did not cause an added effect to CR staining; the saturation values reached their maximum levels when pectinases were applied, even in samples not previously treated at high temperature (Fig. 3B). Therefore, accessibility of cell wall $(1 \rightarrow 4)-\beta-D-$ glucopyranosyl polysaccharides by $\mathrm{CR}$ in samples treated at $125^{\circ} \mathrm{C}$ for 25 min was equivalent to enzyme-treated samples. As discussed above, the applied enzyme conditions are assumed to depolymerise pectin in the cell wall, consequently changing its solubility properties and probably partly removing the pectin from the cell wall. The results clearly showed that cellulose in carrot-based cell clusters is far more accessible for a dye such as CR in samples where cell wall pectin has been depolymerised. This indicates that thermal treatments as well as treatments with pectinases change the cell wall polysaccharide network in such a way that transport phenomena through the cell wall are affected. In this study, the use of CR and the associated measurement of the colour saturation in specimens under bright field light microscopy have been shown to be appropriate to assess these changes in cell wall porosity.

\subsection{Effect of thermal processing and enzyme treatment on anti-crystalline cellulose immunolabelling}

CBM3a is a recombinant carbohydrate-binding module (CBM) protein which confers very high probe specificity for crystalline cellulose (Blake et al., 2006). Results for CBM3a immunolabelling (Fig. 4) followed the same trend as the results for CR staining (Fig. 2), showing a clear increase in labelling intensity when high temperature was applied or when pectin was subjected to the action of pectinases. Again, combining these two treatments did not result in an increase in the labelling intensity. These results are in agreement with the work of Blake et al. (2006), who reported an increased detection of cellulose by CBM's in celery after the enzymatic hydrolysis of pectin.

Upon combining the results of JIM7 labelling, CR staining and CBM3a labelling, it becomes clear that 'native' pectin in carrot cell wall hinders relatively small compounds, such as CR (696.7 Da), to access its adsorption sites on cellulose. Also larger molecules, such as CBM3a (a protein of 155 amino acids, Tormo et al., 1996), are hindered to access its specific cellulose binding sites when 'native' pectin is present in the cell wall of raw carrot tissue. It has been found that $\mathrm{CR}$ adsorption on cellulose mainly results from electrostatic and hydrogen-bonding interactions to the hydrophilic surface of cellulose (Woodcock et al., 1995), although a van der Waals interaction with hydrophobic sites of cellulose may contribute (Mazeau \& Wyszomirski, 2012). On the other hand, it has been shown that the binding mechanism of CBM's on cellulose relies

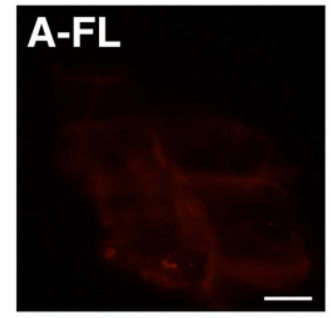

A

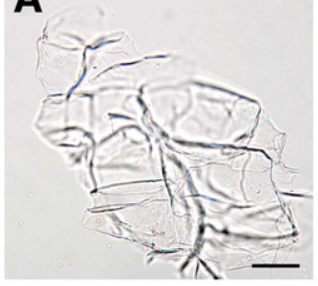

F

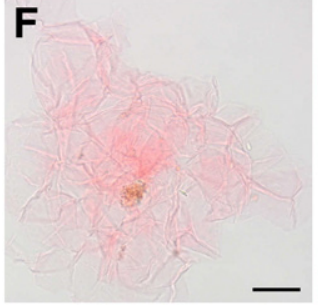

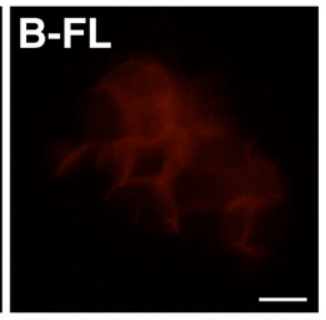

B

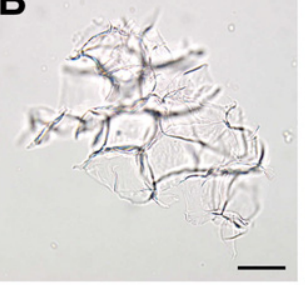

G

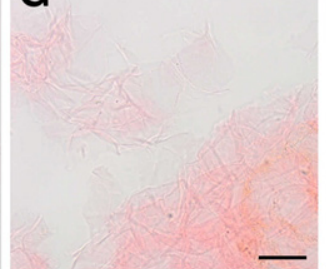

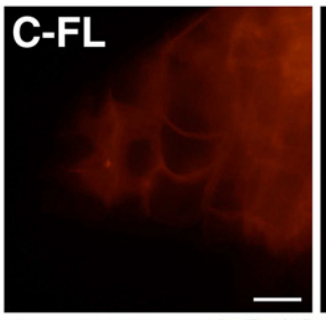
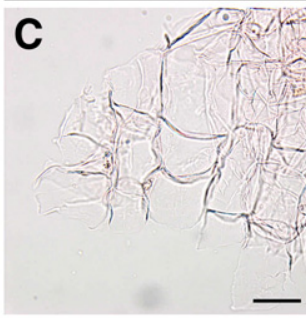

H

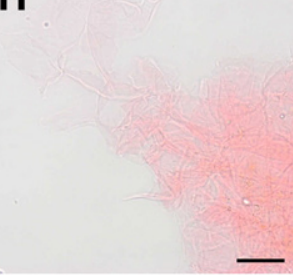

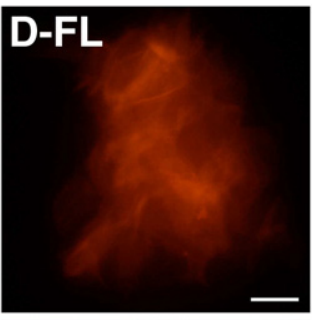

D
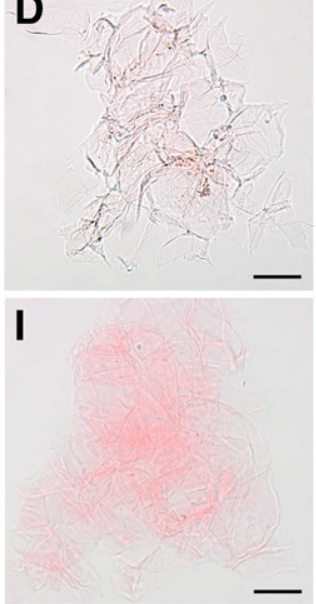

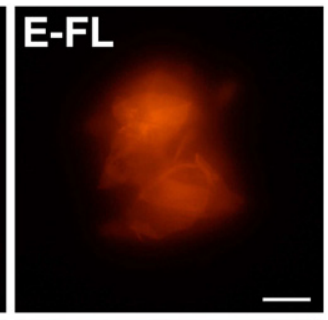

E

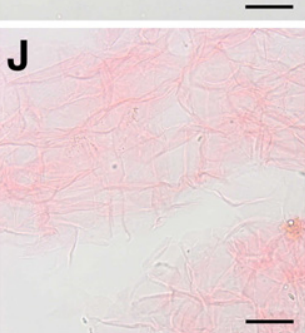

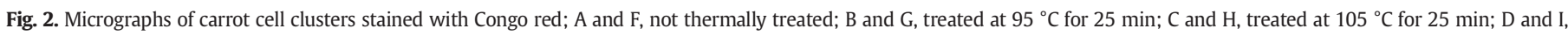

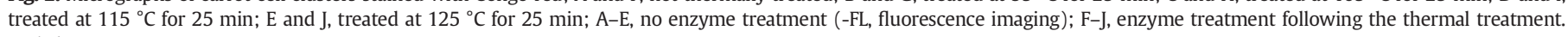
Scale bars $=50 \mu \mathrm{m}$. 
Version définitive du manuscrit publiée dans / Final version of the manuscript published in :

Innovative Food Science and Emerging Technologies (2014), Vol. 24, p. 113-120,

DOI: 10.1016/j.ifset.2013.09.005 - Journal homepage : www.elsevier.com/locate/ifset
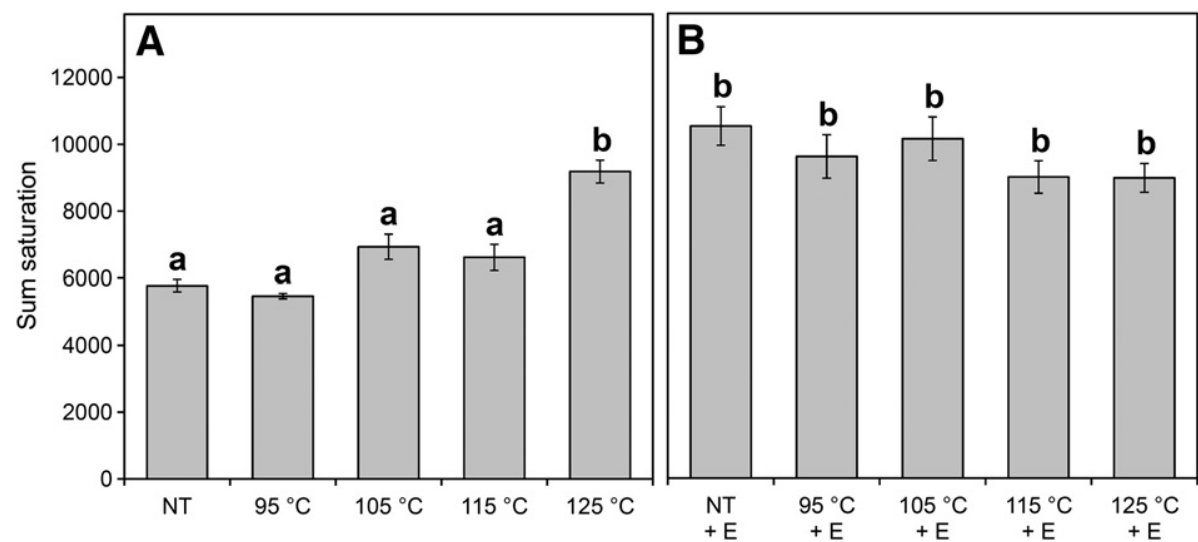

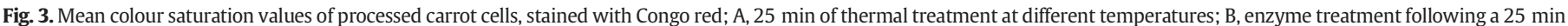

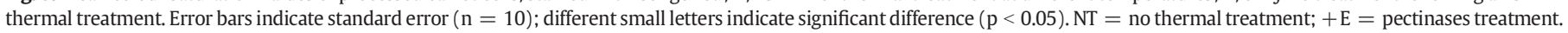

on hydrophobic interaction (Lehtiö et al., 2003). The present work shows that the pectic barrier to both kind of interactions (CR and CBM3a) was released after pectin changes by thermal treatment and/ or enzymatic treatment.

\subsection{Effect of thermal processing and enzyme treatment on anti-hemicelluloses immunolabelling}

As observed for cellulose (CR and CBM3a), all the hemicellulosedirected probes used in this work, except LM21, resulted in intensely labelled carrot-based cell clusters in case the cell wall pectin was depolymerised. Comparable fluorescent images were obtained for thermally treated samples, enzymatically treated samples and samples that underwent a thermal treatment as well as an enzyme treatment, indicating a comparable effect of all these treatments on pectin polymers (Fig. 5).

Xyloglucans are the major class of hemicelluloses in the primary cell wall of most vascular plants. They strongly interact with cellulose microfibrils and are considered a main structural feature in the loadbearing function of the cell wall (O'Neill \& York, 2003). LM15 binds selectively to XXXG- and XXGG-type xyloglucans (Marcus et al., 2008). XXXG-type xyloglucans are the most common structure of xyloglucans in plants such as carrot, while XXGG-type is present in Solanaceae and Poaceae plants (O'Neill \& York, 2003). The effect of pectinases and/or thermal treatment on carrot cells caused an increased detection of xyloglucans (Fig. 5), in agreement with the results of Marcus et al. (2008), who observed increased detection in pea and tobacco after enzymatic treatment.
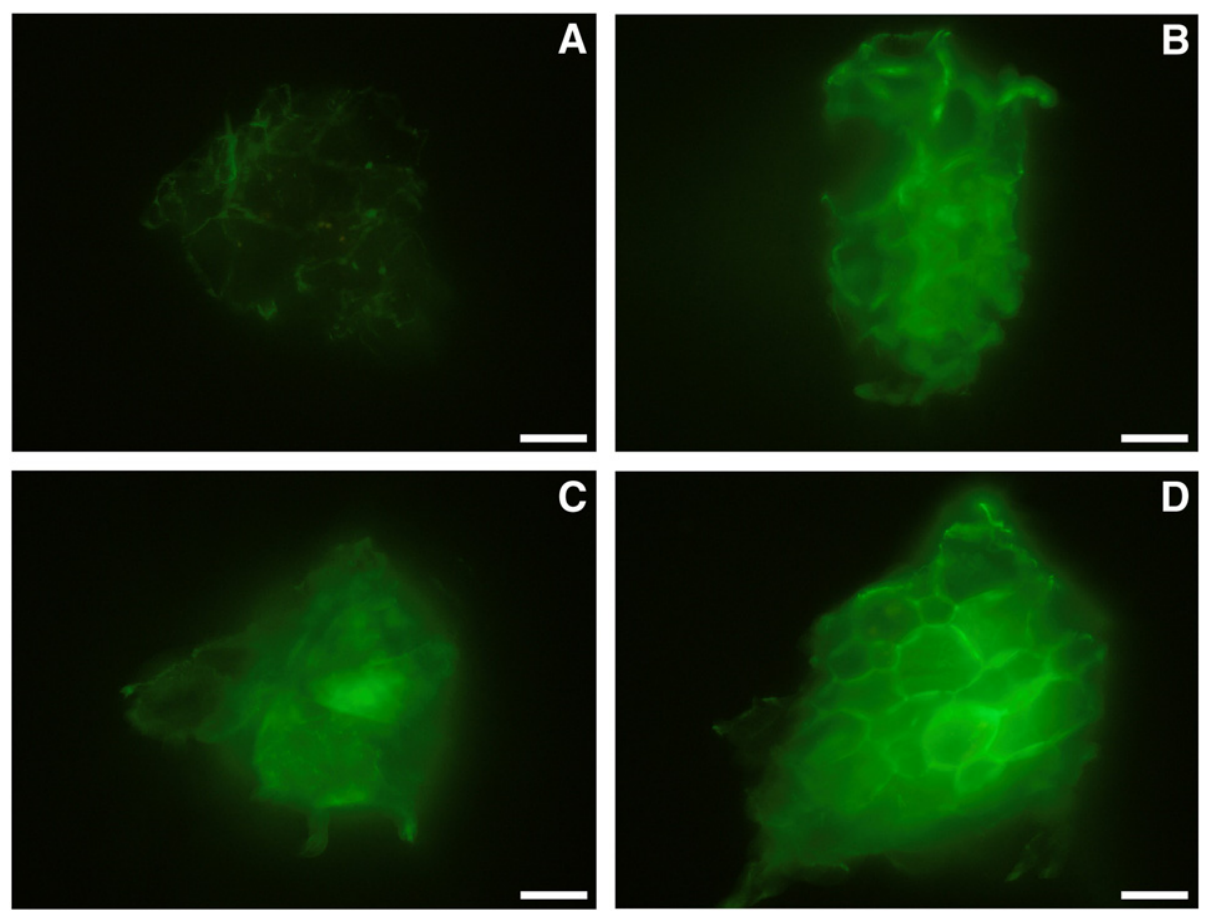

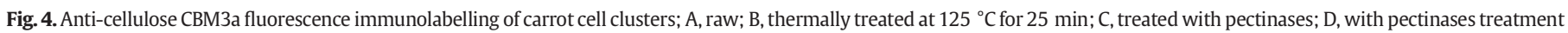
following thermal treatment. Scale bars $=50 \mu \mathrm{m}$. 
LM11
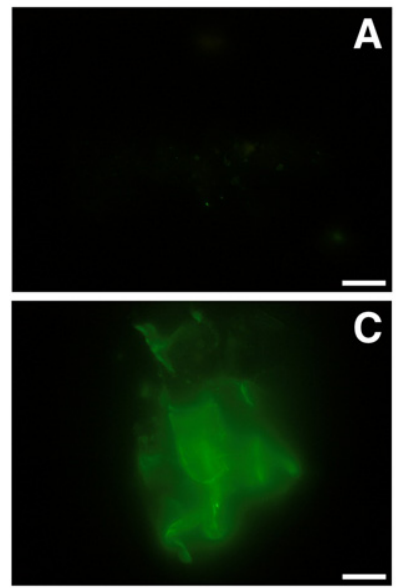

LM21
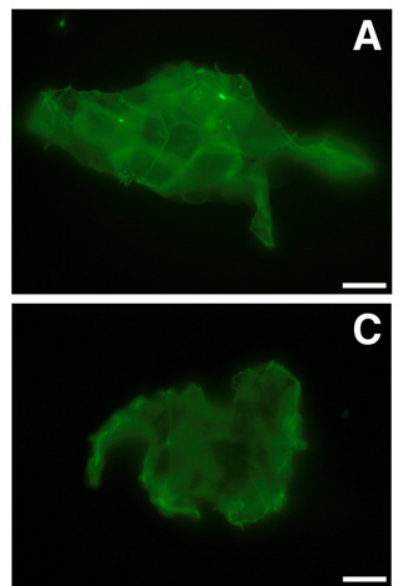
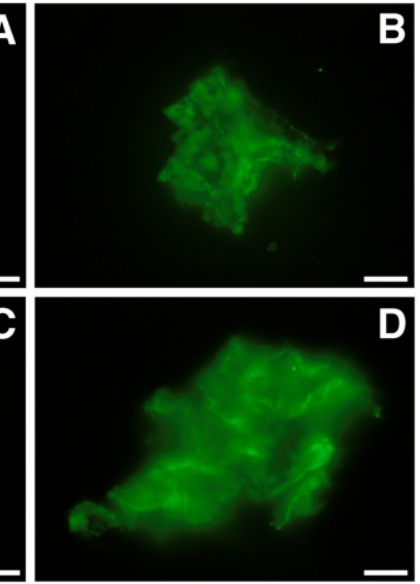

D

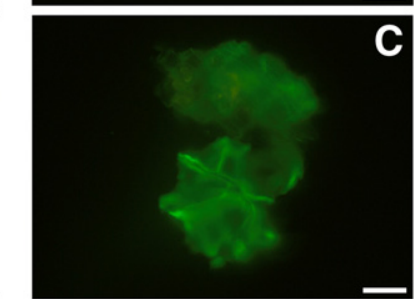

\section{LM22}
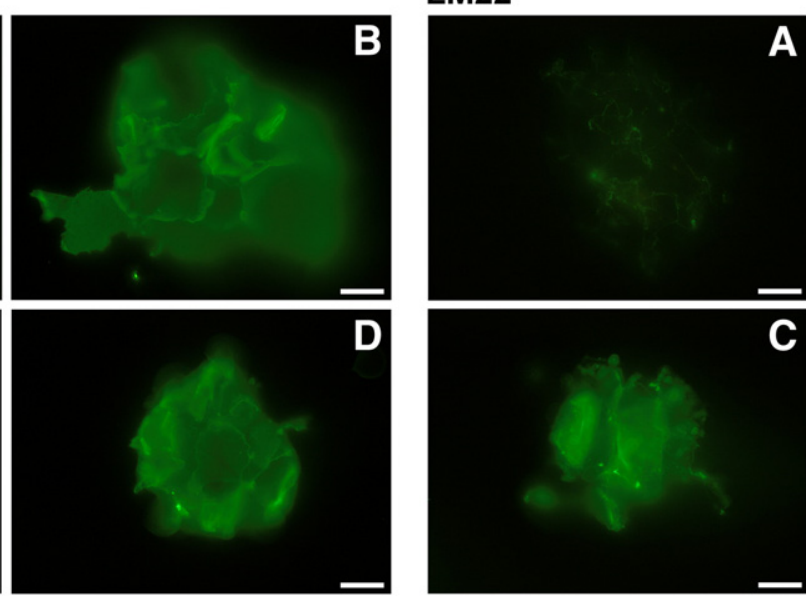

\section{LM15}
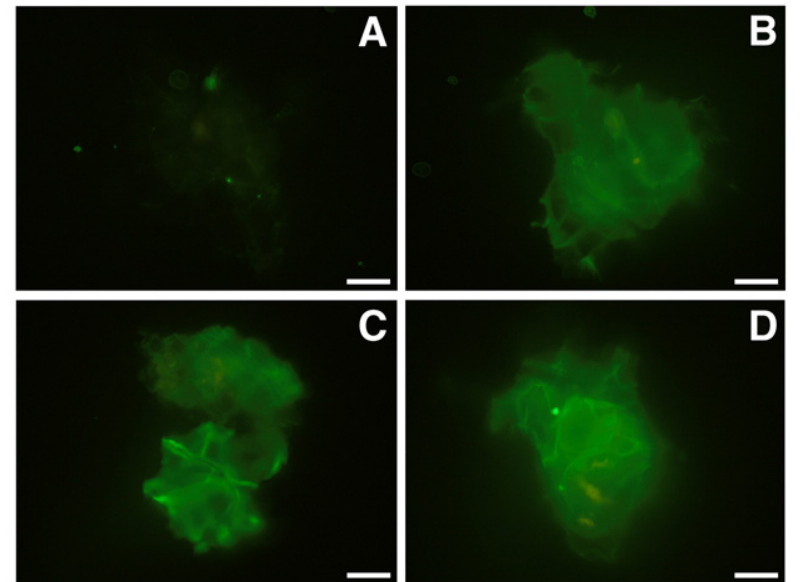
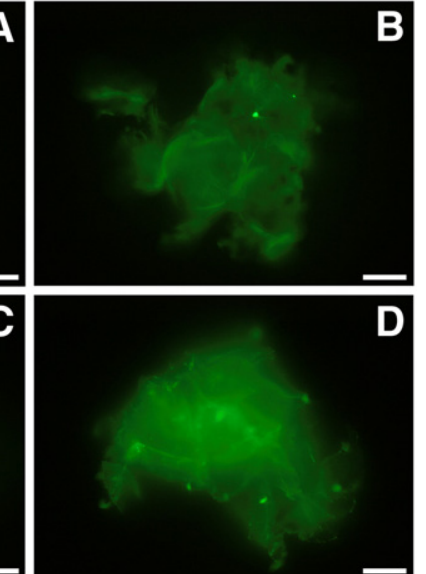

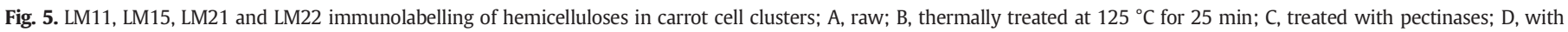
pectinases treatment following thermal treatment. Scale bars $=50 \mu \mathrm{m}$.

Xylans are minor components of the primary cell walls in dicotyledons (O'Neill \& York, 2003). As described above, LM11 immunolabelling, directed to un-substituted and low-substituted xylans and arabinoxylans (McCartney, Marcus, \& Knox, 2005), showed an increased fluorescence when pectin was affected, either by pectinases or by high temperature. The pictures clearly show that pectin also restricts the accessibility of xylans (Fig. 5).

LM10, on the other hand, did not show affinity to the different samples. In the raw samples as well as in the thermal processed and enzyme treated samples no labelling was observed. LM10 is a monoclonal antibody that recognises un-substituted and relatively low-substituted xylans in several species (McCartney et al., 2005). The fact that this probe showed no affinity towards the samples in this study most probably indicates that the LM10 epitope is absent in carrot-based tissue particles.

LM21 is a monoclonal antibody able to specifically detect mannan polysaccharides (Marcus et al., 2010), a group which includes mannan, glucomannans (mannans with glucosyl residues in the backbone), galactomannans (galactosyl residues) and galactoglucomannans (both glucosyl and galactosyl residues). Amongst all the tested probes towards cellulose and hemicelluloses, LM21 was the only one whose affinity was not hampered by the presence of 'native' pectin (Fig 5). A similar observation was reported by Marcus et al. (2010) in the bryophyte Physcomitrella patens, where no increase was observed in LM21 recognition after pectinase treatment. However, the same authors reported increased cell wall detection by LM21 after pectinase treatment in parenchyma primary cell walls of Arabidopsis thaliana, tobacco, pea and the fern Hymenasplenium obscurum.
Interestingly, LM22, another mannan group-specific probe (Marcus et al., 2010), showed a lower labelling intensity in the non-treated sample compared to the samples in which pectin was affected by the applied thermal and/or enzymatic treatment (Fig. 5). The observed differences between LM21 and LM22 binding activities might be due to differences in the capacity of both antibodies to penetrate into the cell wall in presence of pectin. However, Marcus et al. (2010) found that both antibodies recognise different epitopes within one particular plant matrix. Whereas LM21 has been observed to bind successfully mannan, glucomannan and galactomannan polysaccharides, LM22 binds mannans except galactomannan. In other words, the most plausible explanation for this differential cell wall recognition is that the binding between LM21 and galactomannan in carrot is not affected by the presence of 'native' pectin. This phenomenon, which contrasts with the fact that all other probes against cellulose and hemicelluloses used in this work showed more affinity towards their epitopes in samples in which pectin was modified, suggests that galactomannan is not as closely linked to pectin and may have an explanation in the context of carrot plant development. Some authors have described functions for mannan polysaccharides other than their structural role: they can also function as a carbohydrate reserve (Buckeridge, Pessoa dos Santos, \& Tiné, 2000; Liepman et al., 2007), with the participation of $\beta$ mannanase and other mannan-degrading enzymes (Moreira \& Filho, 2008). If we consider that an increased accessibility to cell wall galactomannan would facilitate its enzymatic hydrolysis, as it is reported for cellulose (Wiman et al., 2012), we can hypothesise that there are galactomannan domains which access is not restricted by pectin, as an exception to the overall carrot cell wall permeability, in order to allow 
the mobilisation of carbohydrate reserves for plant metabolism from the enzymatic hydrolysis of galactomannan. Further research in this area is required to fully support this hypothesis.

\section{Conclusion}

The effect of high temperature on the cell wall-binding properties of Congo red and specific anti-polysaccharide probes is reported for the first time in literature. The striking similarities of the results obtained upon thermal treatment and enzyme treatment (PME and PG) prove that thermal processing affects pectin in carrot cell wall.

Native pectin hindered a wide range of cell wall polysaccharidecompound interactions, including $i$ ) the interaction between cellulose and $\mathrm{CR}$, a relatively small compound of 696.7 Da that mainly interacts with cellulose via hydrophilic-dominated bonding; ii) the interaction between cellulose and CBM3a, that has a 155 amino acid structure and interacts with cellulose via hydrophobic-dominated bonding; and iii) the specific interactions of antibodies with xyloglucans, xylans, arabinoxylans and mannans (except galactomannan). The fact that this wide range of interactions was clearly enhanced upon pectin depolymerisation and solubilisation, induced either thermally or enzymatically, suggests strong interaction of pectin with the other polysaccharides in the cell wall, creating a densely-packed polysaccharide network in which pectin plays an important role in terms of barrier properties. Immunodetection of galactomannan was independent of the status of cell wall pectin, probably due to the participation of this hemicellulose polymer in plant metabolism, for which galactomannan would be out of the pectin-mediated barrier network in order to be reachable by plant enzymes.

The results also showed how the barrier properties of the cell wall polysaccharide network in carrot can be disabled through thermal processing, possibly affecting functionalities such as carotenoid bioaccessibility. Finally, the use of Congo red and anti-polysaccharide molecular probes and monoclonal antibodies combined with light microscopy and fluorescence light microscopy have been proven as novel approaches investigating changes in the cell wall barrier properties upon food processing.

\section{Acknowledgements}

This work was financially supported by the European Commission, Seventh Framework Programme (FP7) Marie Curie Actions 'HST Food Train'. Sandy Van Buggenhout is a postdoctoral researcher of the Research Foundation Flanders (FWO). The authors gratefully acknowledge and thank Margot de Haes and Heidi Roba for the technical assistance and Prof. Paul Knox of the University of Leeds (UK) for the generous gift of molecular probes for cell wall polymers.

\section{References}

Agoda-Tandjawa, G., Durand, S., Gaillard, C., Garnier, C., \& Doublier, J. L. (2012). Properties of cellulose/pectins composites: Implication for structural and mechanical properties of cell wall. Carbohydrate Polymers, 90, 1081-1091.

Bhattacharya, S., Ghosh, J. S., Sahoo, D. K., Dey, N., \& Pal, A. (2010). Screening of superior fiber-quality-traits among wild accessions of Bambusa balcooa: efficient and non-invasive evaluation of fiber developmental stages. Annals of Forest Science, 67, 611.

Blake, A. W., McCartney, L., Flint, J. E., Bolam, D. N., Boraston, A.B., Gilbert, H. J., et al. (2006). Understanding the biological rationale for the diversity of cellulose-directed carbohydrate-binding modules in prokaryotic enzymes. Journal of Biological Chemistry, 281, 29321-29329.

Buckeridge, M. S., Pessoa dos Santos, H., \& Tiné, M.A. S. (2000). Mobilisation of storage cell wall polysaccharides in seeds. Plant Physiology and Biochemistry, 38, 141-156.

Castleman, K. R. (1998). Concepts in imaging and microscopy: Color image processing for microscopy. The Biological Bulletin, 194, 100-107.

Christiaens, S., Van Buggenhout, S., Ngouémazong, E. D., Vandevenne, E., Fraeye, I., Duvetter, T., et al. (2011). Anti-homogalacturonan antibodies: A way to explore the effect of processing on pectin in fruits and vegetables? Food Research International, 44, 225-234.
De Roeck, A., Sila, D. N., Duvetter, T., Van Loey, A., \& Hendrickx, M. (2008). Effect of high pressure/high temperature processing on cell wall pectic substances in relation to firmness of carrot tissue. Food Chemistry, 107, 1225-1235.

Jolie, R. P., Christiaens, S., De Roeck, A., Fraeye, I., Houben, K., Van Buggenhout, S., et al. (2012). Pectin conversions under high pressure: Implications for the structure-related quality characteristics of plant-based foods. Trends in Food Science E' Technology, 24, 103-118.

Knockaert, G., De Roeck, A., Lemmens, L., Van Buggenhout, S., Hendrickx, M., \& Van Loey, A. (2011). Effect of thermal and high pressure processes on structural and health-related properties of carrots (Daucus carota). Food Chemistry, 125, 903-912.

Knockaert, G., Lemmens, L., Van Buggenhout, S., Hendrickx, M., \& Van Loey, A. (2012). Changes in $\beta$-carotene bioaccessibility and concentration during processing of carrot puree. Food Chemistry, 133, 60-67.

Knox, J. (1997). The use of antibodies to study the architecture and developmental regulation of plant cell walls. International Review of Cytology, 171, 79-120.

Lehtiö, J., Sugiyama, J., Gustavsson, M., Fransson, L., Linder, M., \& Teeri, T. T. (2003). The binding specificity and affinity determinants of family 1 and family 3 cellulose binding modules. Proceedings of the National Academy of Sciences of the United States of America, 100, 484-489.

Lemmens, L., Colle, I. J. P., Van Buggenhout, S., Van Loey, A.M., \& Hendrickx, M. E. (2011) Quantifying the influence of thermal process parameters on in vitro $\beta$-carotene bioaccessibility: A case study on carrots. Journal of Agricultural and Food Chemistry, 59, 3162-3167.

Lemmens, L., Van Buggenhout, S., Van Loey, A.M., \& Hendrickx, M. E. (2010). Particle size reduction leading to cell wall rupture is more important for the $\beta$-carotene bioaccessibility of raw compared to thermally processed carrots. Journal of Agricultural and Food Chemistry, 58, 12769-12776.

Liepman, A. H., Nairn, C. J., Willats, W. G. T., Sørensen, I., Roberts, A. W., \& Keegstra, K. (2007). Functional genomic analysis supports conservation of function among cellulose synthase-like A gene family members and suggests diverse roles of mannans in plants. Plant Physiology, 143, 1881-1893.

Lopez-Sanchez, P., Nijsse, J., Blonk, H. C. G., Bialek, L., Schumm, S., \& Langton, M. (2011). Effect of mechanical and thermal treatments on the microstructure and rheological properties of carrot, broccoli and tomato dispersions. Journal of the Science of Food and Agriculture, 91, 207-217.

Marcus, S. E., Blake, A. W., Benians, T. A. S., Lee, K. J.D., Poyser, C., Donaldson, L., et al. (2010). Restricted access of proteins to mannan polysaccharides in intact plant cell walls. The Plant Journal, 64, 191-203.

Marcus, S., Verhertbruggen, Y., Hervé, C., Ordaz-Ortiz, J., Farkas, V., Pedersen, H., et al. (2008). Pectic homogalacturonan masks abundant sets of xyloglucan epitopes in plant cell walls. BMC Plant Biology, 8, 60 .

Mazeau, K., \& Wyszomirski, M. (2012). Modelling of Congo red adsorption on the hydrophobic surface of cellulose using molecular dynamics. Cellulose, 19, 1495-1506.

McCartney, L., Marcus, S. E., \& Knox, J. P. (2005). Monoclonal antibodies to plant cell wall xylans and arabinoxylans. Journal of Histochemistry and Cytochemistry, 53, 543-546.

Moelants, K., Jolie, R., Palmers, S., Cardinaels, R., Christiaens, S., Buggenhout, S., et al. (2012). The effects of process-induced pectin changes on the viscosity of carrot and tomato sera. Food and Bioprocess Technology, 1-14.

Moelants, K., Lemmens, L., Vandebroeck, M., Van Buggenhout, S., Van Loey, A., \& Hendrickx, M. (2012). Relation between particle size and carotenoid bioaccessibility in carrot- and tomato-derived suspensions. Journal of Agricultural and Food Chemistry, 60, 11995-12003.

Moreira, L. R. S., \& Filho, E. X. F. (2008). An overview of mannan structure and mannan-degrading enzyme systems. Applied Microbiology and Biotechnology, 79, $165-178$.

Morris, V. J., Ring, S. G., MacDougall, A. J., \& Wilson, R. H. (2003). Biophysical characterization of plant cell walls. In J. K. C. Rose (Ed.), The plant cell wall (pp. 55-91). Oxford: Blackwell Publishing, CRC Press.

Nishino, H., Murakoshi, M., Tokuda, H., \& Satomi, Y. (2009). Cancer prevention by carotenoids. Archives of Biochemistry and Biophysics, 483, 165-168.

O'Neill, M., \& York, W. (2003). The composition and structure of plant primary cell walls. In J. K. C. Rose (Ed.), The plant cell wall (pp. 1-54). Oxford: Blackwell Publishing, CRC Press.

Palmero, P., Lemmens, L., Ribas-Agustí, A., Sosa, C., Met, K., de Dieu Umutoni, J., et al. (2013). Novel targeted approach to better understand how natural structural barriers govern carotenoid in vitro bioaccessibility in vegetable-based systems. Food Chemistry, 141, 2036-2043.

Rao, A. V., \& Rao, L. G. (2007). Carotenoids and human health. Pharmacological Research, $55,207-216$.

Sandhu, A. P.S., Randhawa, G. S., \& Dhugga, K. S. (2009). Plant cell wall matrix polysaccharide biosynthesis. Molecular Plant, 2, 840-850.

Sila, D. N., Smout, C., Elliot, F., Van Loey, A., \& Hendrickx, M. (2006). Non-enzymatic depolymerization of carrot pectin: Toward a better understanding of carrot texture during thermal processing. Journal of Food Science, 71, E1-E9.

Thomas, L. H., Forsyth, V. T., Šturcová, A., Kennedy, C. J., May, R. P., Altaner, C. M., et al. (2013). Structure of cellulose microfibrils in primary cell walls from collenchyma. Plant Physiology, 161, 465-476.

Thompson, J., \& Fry, S. (2000). Evidence for covalent linkage between xyloglucan and acidic pectins in suspension-cultured rose cells. Planta, 211, 275-286.

Tormo, J., Lamed, R., Chirino, A. J., Morag, E., Bayer, E. A., Shoham, Y., et al. (1996). Crystal structure of a bacterial family-III cellulose-binding domain: a general mechanism for attachment to cellulose. The EMBO Journal, 15, 5739.

Van Buggenhout, S., Ahrné, L., Alminger, M., Andrys, A., Benjamin, M., Bialek, L., et al. (2012). Structural design of natural plant-based foods to promote nutritional quality. Trends in Food Science E' Technology, 24, 47-59. 
Version définitive du manuscrit publiée dans / Final version of the manuscript published in : Innovative Food Science and Emerging Technologies (2014), Vol. 24, p. 113-120, DOI: 10.1016/j.ifset.2013.09.005 - Journal homepage : www.elsevier.com/locate/ifset

Van Buggenhout, S., Alminger, M., Lemmens, L., Colle, I., Knockaert, G., Moelants, K., et al (2010). In vitro approaches to estimate the effect of food processing on carotenoid bioavailability need thorough understanding of process induced microstructural changes. Trends in Food Science \& Technology, 21, 607-618.

Verbelen, \& Kerstens (2000). Polarization confocal microscopy and Congo red fluorescence: A simple and rapid method to determine the mean cellulose fibril orientation in plants. Journal of Microscopy, 198, 101-107.

Wallace, I., \& Anderson, C. T. (2012). Small molecule probes for plant cell wall polysaccharide imaging. Frontiers in Plant Science, 3.

Wang, T., Zabotina, O., \& Hong, M. (2012). Pectin-cellulose interactions in the Arabidopsis primary cell wall from two-dimensional magic-angle-spinning solid-state nuclear magnetic resonance. Biochemistry, 51, 9846-9856.

Willats, W. G. T., McCartney, L., Mackie, W., \& Knox, J. P. (2001). Pectin: Cell biology and prospects for functional analysis. Plant Molecular Biology, 47, 9-27.
Willats, W. G. T., Steele-King, C. G., McCartney, L., Orfila, C., Marcus, S. E., \& Knox, J. P. (2000). Making and using antibody probes to study plant cell walls. Plant Physiology and Biochemistry, 38, 27-36.

Wiman, M., Dienes, D., Hansen, M.A. T., van der Meulen, T., Zacchi, G., \& Lidén, G. (2012) Cellulose accessibility determines the rate of enzymatic hydrolysis of steampretreated spruce. Bioresource Technology, 126, 208-215.

Wood, P. J. (1980). Specificity in the interaction of direct dyes with polysaccharides. Carbohydrate Research, 85, 271-287.

Wood, P. J., Fulcher, R. G., \& Stone, B.A. (1983). Studies on the specificity of interaction of cereal cell wall components with Congo red and Calcofluor. Specific detection and histochemistry of $(1 \rightarrow 3),(1 \rightarrow 4),-\beta-D-$ glucan. Journal of Cereal Science, 1 95-110.

Woodcock, S., Henrissat, B., \& Sugiyama, J. (1995). Docking of Congo red to the surface of crystalline cellulose using molecular mechanics. Biopolymers, 36, 201-210. 